\title{
Cardiac Arrest as a Complication of H1N1 Infection: A Case Report from India
}

\author{
Tushar Parmar and Suvadeep Sen* \\ Department of Critical Care, Apollo Hospital Navi Mumbai, India
}

Submission: March 07, 2018; Published: March 13, 2018

*Corresponding author: Suvadeep Sen, Department of Critical Care, Apollo Hospital Navi Mumbai, Maharashtra 400614, India, Tel: +919702359735; Email: s.sen2011@outlook.com

\begin{abstract}
We report a case of 39-year-old male, diagnosed with H1N1 infection, who presented with bradycardia followed by cardiac asystole requiring CPR. He required temporary pacemaker support for two days for AV block. His rhythm disturbance reverted to normal after starting treatment of H1N1 with oseltamivir. He was discharged from hospital with full neurological recovery. High degree AV block is a rare but devastating complication of H1N1 infection and is fully reversible after treatment. This case, reports a relatively lesser known complication of H1N1 infection on cardiac conduction system.
\end{abstract}

Keywords: H1N1 infection; Influenza complication; Cardiac arrest

Abbreviations: WHO: World Health Organisation; OPD: Outpatient Department; CPR: Cardiopulmonary Resuscitation; ROSC: Return of Spontaneous Circulation; TSH: Thyroid Stimulating Hormone; TPO: Thyroid Peroxidase Antibody; Anti-TG: Antithyroglobulin; ACE: Angiotensin Converting Enzyme; PCR: Polymerase Chain Reaction; ARDS: Acute Respiratory Distress Syndrome; ANA: Anti-Nuclear Antibody

\section{Introduction}

H1N1 influenza is a common respiratory disease across the globe. In 2009 WHO (World Health Organisation), declared first pandemic for H1N1 infection worldwide. Spontaneous genetic reassortment gives influenza virus a unique ability to avert protective immunity in human being and to cause recurrent epidemic and global pandemic. While most of the cases are self-limiting, H1N1 infection may be life threatening. The mortality is especially high in extremes of ages, pregnant, immunocompromised and with co morbidities. In this report we have documented a rare but potentially life-threatening complication of H1N1 infection in a young apparently healthy adult Indian male.

\section{Presentation of Case}

39-year male, came to OPD with history of fever, malaise, throat pain and cough for 3 days. While being evaluated in OPD, he had one episode of syncope. ECG revealed to have sinus bradycardia. While being monitored, his ECG soon degenerated to complete heart block and then to asystole. He was revived after immediate CPR of one cycle along with adrenaline. Post resuscitation, ECG revealed to have sinus bradycardia, with QTc of $409 \mathrm{~m}$-sec with T inversion in lead III and AVF. He was shifted to intensive care unit for observation where he had another episode of cardiac arrest with asystole. ROSC achieved after one cycle of CPR with full regain of consciousness. Post resuscitation he was shifted to Cath-lab, where cardiac angiography was done and found to be normal. Temporary pace maker was inserted. His Cardiac enzymes came normal, 2D Echocardiography was found to be having normal systolic and diastolic function with normal valves and no regional wall motion abnormality. His serial ECGs were unremarkable except for sinus bradycardia.

Among other investigations, his white blood cell count was $7.42 \times 109 / \mathrm{L}$, haemoglobin was $13.9 \mathrm{~g} / \mathrm{dl}$, platelet count was $141 \times 109 / \mathrm{L}$, serum electrolytes normal, liver function test normal, serum calcium $2 \mathrm{mmol} / \mathrm{L}$ with serum albumin $3.4 \mathrm{mg} /$ dl, C-Reactive protein: $17 \mathrm{mg} / \mathrm{L}$, TSH $7.71 \mathrm{mIU} / \mathrm{L}$. Dengue NS1 was sent in view of fever with mild thrombocytopenia and throat swab for H1N1 was sent in view of concomitant clinical picture and high endemic nature of the infection in our area. Retroviral status was negative. The patient had undergone a regular health check-up 3 month back, where his ECG was normal. He did not have any complain of chest pain or palpitation in the recent past. He was diagnosed to be hypothyroid three months back, when his TSH was found to be $55.5 \mathrm{mIU} / \mathrm{ml}$ and Anti-TPO $1300 \mathrm{IU} / \mathrm{ml}$, Anti-TG $103 \mathrm{IU} / \mathrm{ml}$. He was started on oral thyroxin 50mcg. Repeat evaluation, after one month, TSH was $20.7 \mathrm{mIU} / \mathrm{ml}$, Anti TPO was $452 \mathrm{IU} / \mathrm{ml}$ and Anti TG was 29.3IU/ml. Anti-nuclear Antibody and serum ACE level was sent and was found normal. Throat swab sent for testing H1N1 came positive for swine flu (Test done by Real time-PCR). He was started on Oseltamivir at $75 \mathrm{mg}$ twice daily dose and was continued for 5 days. His subsequent stay 
in hospital was uneventful. Heart rate improved after starting oseltamivir. Temporary pace maker was removed after two days of observation. He was discharged from hospital after 5 days.

\section{Discussion}

Seasonal influenza is endemic in our country and has high incidence of mortality and morbidity. It is caused by Influenza virus type A. Influenza virus is a RNA virus belonging to Orthomyxoviridae family. The subtypes are based on the combination of $\mathrm{H}$ (Haemagglutinin) and $\mathrm{N}$ (Neuraminidase) surface glycoproteins. Hemagglutinin antigens are of 18 different subtypes and neuraminidase is of 11 different subtypes [1]. Influenza A can infect multiple species like human, avian and swine. The virus has a high rate of genetic plasticity in form of antigenic drift and antigenic shift. Antigenic drift is small genetic changes in form of point mutation that occurs relatively often, and which enables influenza virus to escape immune recognition and cause repeated outbreaks during same years. Antigenic shift is abrupt major changes in hemagglutinin or neuraminidase protein that results in new influenza a subtype. Swine Flu is influenza virus subtype H1N1 that can cause epidemics, outbreaks and sporadic cases. Source of infection is clinical and subclinical cases. Transmission is mainly airborne droplets from infected human being. The virus remains communicable for initial 3-5 days of clinical onset in adults with peak virus shedding on day one of symptoms. There is no cross-immunity between different subtypes/strains. In tropics and subtropical climate, epidemic occurs in rainy season. Sporadic cases can occur throughout the year. Case fatality rate, as described in a surveillance study in England during 2009 pandemic was $0.026 \%$ [2]. According to Indian data case fatality rate is much higher (more than $50 \%$ in selected area [3]), though the statistics may reflect gross under reporting of the cases across the nation. In 2017, there were 38811 laboratory confirmed cases and 2266 deaths among them [4].

Influenza is a predominantly respiratory infection and major clinical symptoms are fever, throat pain, with cough. For most of the patients the course subsides uneventfully within few days without major complications. For some patients, the infection turns aggressive and may lead to ARDS, pneumonia and respiratory failure. Cardiac complications are rare and can range from myocarditis (incidence rate 9\% [5]), acute coronary symptoms [6] and various conduction defects like bundle branch block, complete atrioventricular (AV) block [7] and asystole. The mechanism of $\mathrm{AV}$ block is not fully understood but is thought because of myocarditis leading to inflammatory cell infiltrates around bundle of His and consequent oedema and necrosis as described in experimental murine model [8]. In our case, the patient was admitted with typical symptoms of H1N1 influenza, and had bradycardia followed by cardiac asystole soon after arriving to hospital. He required temporary pacemaker support for brief period. He was started with oseltamivir and his heart rate improved within next 48 hrs. The relation between H1N1 and Brady-asystolic arrest was temporal and was supported by similar case reports in medical literature [7-10]. Other causes of bradyarrhythmia were evaluated.

a. Coronary angiography was normal that rules out the acute coronary event,

b. 2D Echocardiography did not revealed any regional wall motion abnormality and infiltrative disease of heart,

c. Serum electrolytes were normal,

d. Thyroid function status was almost within normal limit with TSH slightly higher than reference range.

e. Serum ACE level was done to rule out sarcoidosis.

f. ANA was done as a screening tool for auto-immune pathology which was negative.

The American Heart Association (AHA) and the American College of Cardiology (ACC) recommends influenza vaccination in adults with coronary and other atherosclerotic vascular diseases as part of secondary prevention [9] that has shown to reduce mortality from cardiovascular disease [10].

\section{Conclusion}

Influenza Type A virus is one of the most common public health problems across the globe. Swine Flu (H1N1) is a zoonotic infection for human and may cause disease ranging from upper respiratory tract infection to fatal ARDS, pneumonia, multi organ failure. Cardiovascular problems are common but often overlooked because of paucity of knowledge and publications in medical literature. While the treatment is relatively simple, the lack of initiation of antiviral may become fatal.

\section{References}

1. (2017) Types of Influenza Viruses. https://www.cdc.gov/flu/about/ viruses/types.htm

2. Donaldson LJ, Rutter PD, Ellis BM, Greaves FE, Mytton OT, et al. (2009) Mortality from pandemic A/H1N1 2009 influenza in England: public health surveillance study. BMJ 339: b5213.

3. Malhotra B, Singh R, Sharma P, Meena D, Gupta J, et.al. (2016) Epidemiological \& clinical profile of influenza A (H1N1) 2009 virus infections during 2015 epidemic in Rajasthan. Indian J Med Res 144(6): 918-923.

4. (2018) Seasonal Influenza (H1N1)-State/UT- wise, Year- wise number of cases and death from 2011 to 2018. http://idsp.nic.in/showfile. php?lid=3933

5. Karjalainen J, Nieminen MS, Heikkila J (1980) Influenza A1 myocarditis in conscripts. Acta Med Scand 207(1-2): 27-30.

6. Madjid M, Casscells SW (2004) Of birds and men: cardiologists' role in influenza pandemics. Lancet 364(9442): 1309

7. Beinart R, Morganti K, Ruskin J, Mela T (2011) H1N1 influenza a virus induced atrioventricular block. J Cardiovasc Electrophysiol 22(6): 711-713.

8. Ohmae M, Kishimoto C, Tomioka N (2005) Complete atrioventricular block in experimental murine myocarditis. J Electrocardiol 38(3): 230-234. 
9. Ciszewski A, Bilinska ZT, Brydak LB, Kepka C, Kruk M, et al. (2008) Influenza vaccination in secondary prevention from coronary ischaemic events in coronary artery disease: FLUCAD study. Eur Heart J 29(11): 1350-1358.

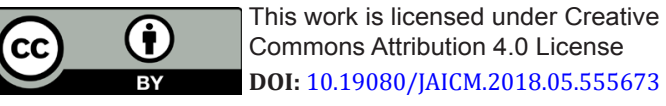

\section{Your next submission with Juniper Publishers will reach you the below assets}

- Quality Editorial service

- Swift Peer Review

- Reprints availability

- E-prints Service

- Manuscript Podcast for convenient understanding

- Global attainment for your research

- Manuscript accessibility in different formats

( Pdf, E-pub, Full Text, Audio)

- Unceasing customer service

Track the below URL for one-step submission https://juniperpublishers.com/online-submission.php 